\title{
Carbon dioxide Concentration in the Atmosphere of Isthripura Cavern, Central Province, Sri Lanka
}

V. BASNAYAKE

Faculty of Medicine, University of Peradeniya, Peradeniya, Sri Lanka.

(Date of receipt: 04 April 1983)

(Date of acceptance: 12 April 1983)

\begin{abstract}
The atmosphere of a more or less horizontal C-shaped limestone cavern at Isthripura, Sri Lanka, showed a gradient of $\mathrm{CO}_{2}$ concentration from nearly $3 \%$ at the closed end of the cavern to $0 \%$ at the open end. The $\mathrm{O}_{2}$ concentrations were everywhere above $18 \%$. The dyspnoea which is experienced inside the cavern seems to be partly due to hypercapnia. The full explanation for the occurrence of marked dyspnoea at certain points in the cavern remains to be found.
\end{abstract}

\section{Introduction}

There are a number of crystalline limestone caves in Sri Lanka. ${ }^{2}$ Two of the larger caves situated in the central region of the country are both called Isthripura. This term is said to be derived from two Sanskrit/Sinhalese roots: sthri, woman; pura, town. The present account is about the Isthripura cavern situated at $80^{\circ} 54^{\prime} \mathrm{E}$, (longitude) and $7^{\circ}$ $10^{\prime} \mathrm{N}$ (latitude). The Mahaweli river flows in the valley about $2 \mathrm{~km}$ away from the cavern. The cavern is expected to be inundated when the Raridenigala dam is built across the river within the next few years. It is hardly visited except occasionally by Buddhist religious groups who meditate in the grotto.

The cavern, situated on hilly ground, consists of three large caves and three small caves, connected by passages (Figure 1). The system is shaped like a horizontal C lying in an east-west direction. Three large caves form the ends and middle of the $C$. The small caves lead off from the passages which connect the large caves. The first large cave, at the east end of the system, is a grotto, open to the exterior, forming the entrance to the cavern. All the other caves and passages are subterranean and black. The mouth of the grotto is about $20 \mathrm{~m}$ wide while its floor is about $55 \mathrm{~m}$ wide. Its long axis lies in a north-south direction. A vertical shaft, about $2.5 \mathrm{~m}$ deep, leads into the rest of the cavern from a point near the north end of the grotto floor. The middle cave, about $85 \mathrm{~m}$ long, is at the lowest level in the cavern system. It contained a pond of clear water in August 1981 (which is a dry season); the sheet of water was about $30 \mathrm{~m}$ long and its depth about $1.5 \mathrm{~m}$. The shore of the pond contained a brownish-black soil, soft to the touch, and teeming with bag worms, crickets and slender red millipedes, all of which started moving about when the light of the lantern fell on them. The roof of the cave contains chandelier-like stalactites. The passage between the first and second large caves (site 4 in the figure) contains a $1 \mathrm{~m}$ tall dagoba-shaped stalagmite. The third large cave is about $70 \mathrm{~m}$ long, and $12 \mathrm{~m}$ wide and $10 \mathrm{~m}$ high in the centre. It forms the 


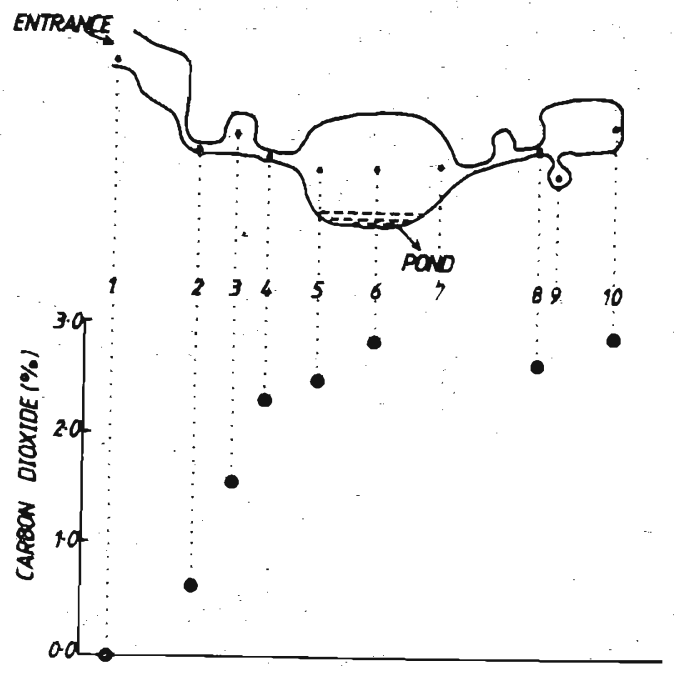

Figure 1 Carbon dioxide concentration in the atmosphere of the Isthripura cavern. The sketch above indicates the general plan of the cavern. It is not drawn to scale. The points on the graph represen the $\mathrm{CO}_{2}$ concentrations at the sites indicated directly above them in the sketch.

far western end of the cavern system. It is the home of a population of bats whose odour first strikes one strongly as one enters the passage leading to the cave.

The cavern is hot and uncomfortable. Respiratory distress in the form of dyspnoea, that is, a conscious awareness that one's breathing is increased and laboured, is experienced, especially at certain points in the natural system of caves and tunnels. It seemed likely that the dyspnoea was due to hypercapnia or hypoxia or both. Deraniyagala ${ }^{3}$ stated that the cavern "air is so deficient in oxygen, that the observer is attacked by a faint sense of dizziness". Gas analysis was not done on that occasion.

\section{Method}

The cavern was visited on 10.8.81 and sites were selected for later study. On 29.8.81 gas was collected into football bladders at the pre-determined sites. This was done by a man who went in alone with an electric torch. The bladders were brought out to the entrance to the cavern and the gas within them was analysed on the spot with a Lloyd-Haldane gas analyser. Each row of figures in the table of results represents a single analysis on gas from a single bladder. 
Subjective sensations were recorded for 3 persons who went into the cavern immediately after the gas samples had been collected. After the three men had returned from the cavern they were asked to make a list of the sensations they had experienced. The composite list was found to be as follows: heat, sweating, breathing difficulty, fear, oppression, fatigue, headache, slipperiness. Each person was then asked to record subjectively the strength of each of these sensations. This was done on a 5 -point rating scale: 0 , no sensation; 1 , slight, mild; 2 , moderate; 3 , marked; 4 , very marked, severe. The results for the three persons were then averaged.

Results are shown in Table 1 and Figure 1.

Table 1.- Carbon dioxide and oxygen concentrations in the atmosphere of the Isthripura cavern

\begin{tabular}{|c|c|c|c|c|}
\hline $\begin{array}{l}\text { Site at which the } \\
\text { gas sample was }\end{array}$ & Bats & $\begin{array}{l}\mathrm{CO}_{2} \\
(\%)\end{array}$ & $\begin{array}{l}\mathrm{O}_{2} \\
(\%)\end{array}$ & $\begin{array}{l}\text { Discomfort score } \\
(0-4 \text { scale })\end{array}$ \\
\hline (See Figure 1) & & & & spnoea Heat \\
\hline
\end{tabular}

1. Entrance to the cavern (a large open cave)

$\begin{array}{llll}0.0 & 20.89 & 0.0 & 0.0 \\ 0.64 & 19.59 & 0.0 & 2.5 \\ 1.55 & 19.25 & 1.2 & 2.5 \\ 1.58 & 18.99 & & \\ 2.31 & 18.28 & 3.7 & 2.1 \\ 2.23 & 18.19 & & \end{array}$

5. Lake, eastern end (near 4 above)

6. Lake, near middle

$2.87 \quad 18.08$

$1.7 \quad 0.0$

7. Lake, western end

8. Passage

9. Cave via a tortuous passage

10. Large cave at South-western end of cavern 


\section{Discussion}

There is no rule that is generally applicable to the gas composition of caverns. Quite apart from sulphurous caves which are suffocating because of hydrogen sulphide (such as in the Death Valley in the Yellowstone of the USA), the $\mathrm{CO}_{2}$ concentration varies enormously. The Grotto of the Fairies at St. Moritz, Switzerland, is said to contain $2 \% \mathrm{CO}_{2}$ and the grotto of Büdösbarlang, Transylvania, 95\% $\mathrm{CO}_{2}^{\prime}$. The term 'foul air' in caves usually denotes air containing much $\mathrm{CO}_{2}{ }^{6}$.

In the Isthripura cavern there was a more or less distinct gradient of carbon dioxide concentrations, with highest levels, nearly $3 \%$, at the western closed end of the cave complex, and decreasing progressively eastwards to the entrance. The open cave at the east end which forms the entrance to the cavern had no more $\mathrm{CO}_{2}$ than ordinary atmospheric air.

The reason for this gradient is not known. We may suppose that $\mathrm{CO}_{2}$ is generated within the cavern and diffuses outwards through the only main exit to the air at the eastern end of the cavern. In other words, the cavern air, laden with $\mathrm{CO}_{2}$; is diluted by atmospheric air the closer it gets to the opening to the atmosphere at the cave entrance. Vertical diffusion gradients of $\mathrm{CO}_{2}$ in vertical shafts is well recognized: The Isthripura cave is more horizontal than vertical.

The mechanism by which $\mathrm{CO}_{2}$ is generated is undetermined. It could be from the action of acidic water percolating into the cavern, liberating $\mathrm{CO}_{2}$ from the calcium carbonate of the limestone rock. The western end of the cavern, rich in $\mathrm{CO}_{2}$, was found to have the wettest rock and soil. Presumably underground water seeps into the cavern especially from the western end at the time of year at which the study was done (August, a non-rainy month for the region). Another important source of $\mathrm{CO}_{2}$ could be the exhalation of bats. Bats were seen emerging from the entrance but none were seen within the caves near the eastern end of the cavern complex. The western caves, on the other hand, had a large population of bats. The bats were medium-sized microchiropterans. ${ }^{7}$

The effect of the cavern atmosphere upon human breathing seemed to be due to several factors, some but not all of which could be identified. The oppressively hot and stuffy atmosphere was probably due to heat and high humidity, although we did not measure these. The dyspnoea was partly due to $\mathrm{CO}_{2} \cdot \mathrm{CO}_{2}$ concentration, which is $0.03 \%$ in ordinary open air, must rise to about $1 \%$ in the inspired air at atmospheric pressure before any measurable increase in the breathing occurs, and this increase is too small to be noticed by the person himself who breathes the air. ${ }^{4}$ Dyspnoea, in the sense of awareness that one's breathing is increased, is known to set in with a $\mathrm{CO}_{2}$ 
concentration of about $2 \%$. The atmosphere in most of the Isthripura cavern, especially its western three-quarters, had $\mathrm{CO}_{2}$ concentrations of the order of $2-3 \%$.

The dyspnoea cannot, however, be fully explained on the basis of the $\mathrm{CO}_{2}$ : concentration alone. The dyspnoea was most marked at two sites in the cavern, neither of which gave the highest $\mathrm{CO}_{2}$ readings. The oxygen concentrations were throughout $18 \%$ or more. These are too high to cause dyspnoea. The full explanation for the oppressive dyspnoea therefore remains to be elucidated. A combination of heat and humidity with excess $\mathrm{CO}_{2}$ and lack of $\mathrm{O}_{2}$ might be the causative agent.

\section{References}

1. CASTERET, N. (1939). Ten years under the earth. London: Dent.

2. COORAY, P. G. (1967). An introduction to the geology of Ceylon. National Museums of Ceylon Publication.

3. DeRAniYagala, P. E. P. (1958). The Pleistocene of Ceylon. Ceylon National Museums Publication.

4. HALDANE, J. S. \& PRIESTLEY, J. G. (1935). Respiration. Oxford: Clarendon Press 2nd ed.

5. JAMES, J. M. (1977). Carbon dioxide in the cave atmosphere. Transactions of the British Cave Research Association, 4:417 - 429.

6. JAMES, J. M., PAVEY, A. J. \& ROGERS, A. F. (1975). Foul air and the hazards to cavers. Transactions of the British Cave Research Association, 2: 79 - 88.

7. PHILliPS, W. W: A. (1935). Manual of the Mammals of Ceylon. Ceylon: The Director, Colombo Museum. London: Dulau \& Co. Ltd. 